\title{
OneBookShelf Community Content Programs and the Polish RPG Fandom
}

\author{
Marek Golonka \\ University of Warsaw, Kazimierz Wielki University in Bydgoszcz \\ marek.golonka92@gmail.com | ORCID:0000-0001-8146-1316
}

\begin{abstract}
The paper analyses the almost complete absence of Polish RPG designers from 0 neBookShelf's community content programs for various tabletop RPG systems, proposing an explanation for this absence based on the development of the RPG fandom in Poland. A part of the argument is concerned with a relatively weak position of Dungeons \& Dragons in Poland compared to the English market and with the Polish RPG players' lack of interest in the market of digital materials for tabletop RPGs. The main hypothesis, however, connects the Polish absence from community content programs with how the long absence of professional systems and the permanently small market of commercial RPGs in Poland might have increased the intensity of prosumption of RPGs among Polish fans but simultaneously limited their chance to gain skills and knowledge necessary to publish and market the results of this prosumption on a professional or semi-professional level. Statements of Jan Sielicki - the only Polish RPG designer who published numerous and successful supplements under community content programs - are quoted to reinforce this hypothesis and show how Sielicki gained the necessary skills outside of the Polish RPG fandom.
\end{abstract}

Keywords: community content, Dungeon Masters Guild, prosumption, roleplaying games, RPG.

Homo Ludens 1(12)/2019 | ISSN 2080-4555 | @ Polskie Towarzystwo Badania Gier 2019 D0I: 10.14746/hl.2019.12.3 | received: 31.12.2018 | revision: 01.06.2019 | accepted: 25.11.2019 

Why are there almost no Polish authors in OneBookShelf community content programs, (i.e., subsites that allow to release materials for various RPGs - DED's Dungeon Masters Guild, $7^{\text {th }}$ Sea's Explorer Society and similar platforms - without gaining a paid license from the system's publisher)? This question came from my review of sources concerning RPG fan prosumption and the history of the roleplaying industry in Poland (Kominiarczuk, 2013; Krawczyk, 2009; Mochocka, Mochocki, 2016; Porczyński, 2014), as well as from my own interaction with and activity within the roleplaying fandom (see Krawczyk, 2010 for an argument for fan expertise as a form of research competence). Both personal observation and research results suggest that the Polish RPG community has a strong prosumptive streak with fan production of materials - both for their own sessions and published online - composing an important part of the overall Polish RPG production.

While I cannot state that this streak is stronger than, for example, in the United States, it is clearly visible and community content programs seem a perfect creative outlet for this sort of fan production. And yet despite my intense search and consulting the Polish fandom in December 2018 I could not find more than three Polish authors publishing their materials via such programs, of whom only one, English-publishing Jan Sielicki, had published more than one material by then. What's more, after reaching Jan and interviewing him about his inspirations and roleplaying background, it turned out that he considered himself an outsider to the elements of Polish roleplaying culture I believed most crucial for the development of the aforementioned prosumptive approach. Is seeing such an approach in Polish RPG culture false? Or maybe it simply does not translate well into the rules by which community content programs run? This article gathers data about both community content programs and Polish roleplaying culture to propose an answer to these questions.

\section{Community content programs}

The history of RPG community content programs started in 2016 when OneBookshelf, the owner of the biggest online RPG stores DriveThruRPG and RPGNow, together with Wizards of the Coast, publisher 
of Dungeons $\mathcal{E}$ Dragons since 1997, announced the creation of Dungeon Masters Guild (OneBookShelf, 2018a). The Guild - a sub-site of OneBookShelf's online store - allows its users to publish various playing materials using the rules of the $5^{\text {th }}$ edition of Dungeons $\mathcal{E}$ Dragons in PDF and other e-book formats; DED-related stock art can also be sold here (Montgomery, 2018a). The Guild does not provide editing or layout services but it does provide art and maps from the earlier editions of the game. The supplements do not get any automatic advertisement but OneBookshelf suggests that creators of the most successful among them might be invited into professional cooperation with the Dungeons $\mathcal{E}$ Dragons publisher (Montgomery, 2018c). The profits from the published materials are divided in a following way: $50 \%$ for the author, $20 \%$ for Wizards of the Coast, and $30 \%$ for OneBookShelf.

For readers acquainted with Wizards of The Coast's previous licensing policy this idea might sound like nothing new or even a step back. Allowing third-party publishers, professional or not, to publish materials for various editions of Dungeons $\mathcal{E}$ Dragons has been the policy of this publisher since the publication of the $3^{\text {rd }}$ edition of the game back in 2000 (Appelcline, 2014b). There is, however, a difference in scope between the earlier licenses and what is allowed on Dungeon Masters Guild. Whereas all the earlier DED licenses allowed their users to reference and expand only on certain parts of the game system (specified in the licenses, but mostly the three core rulebooks, for details see Appelcline, 2014b), titles published in Dungeon Masters Guild can reference almost any part of the Dungeons $\mathcal{E}$ Dragons $5^{\text {th }}$ edition product line, as well as other supplements published on this platform and even materials from earlier editions, including background material for settings already published for $5 \mathrm{E}$ (Forgotten Realms, Ravenloft, Eberron) as long as the published supplement itself was using $5^{\text {th }}$ edition rules (Montgomery, 2018a). While publishers creating supplements using earlier licenses were able to create their own supplements under DED rules, the Guild allows its users to create supplements for $D E D 5 E$ product line.

Another key difference is that previous DED licenses were targeted at publishers, and the Guild is intended for the users. Anyone with a client account on any of OneBookShelf stores can publish content in Dungeon Masters Guild and have their royalties transferred to their PayPal account 
(Montgomery, 2018b). At the same time publishing RPG materials in OneBookShelf RPG shops - RPGNow and DriveThruRPG - requires creating a separate publisher account (Montgomery, 2017). That is the meaning behind calling Dungeon Masters Guild a "community content" program.

Dungeons \& Dragons has been the first RPG to be included in such a program but since the announcement of Dungeon Masters Guild publishers of other roleplaying systems have also started their community content programs with OneBookShelf. The programs currently available are Storyteller's Vault for World of Darkness (including Chronicles of Darkness), Miskatonic Repository for Call of Cthulhu's $7^{\text {th }}$ edition, Explorer's Society for $7^{\text {th }}$ Sea's $2^{\text {nd }}$ edition, and many more (OneBookShelf, 2018b). New RPG publishers are gradually joining this trend - for example, on $11^{\text {th }}$ December 2018 Pinnacle Entertainment Group announced an upcoming community content program called Savage Worlds Adventurer's Guild (Pinnacle, 2018).

\section{2. "Community content" of Polish tabletop RPG fandom}

Creating "community content" - in the broader sense of this phrase, not connected with OneBookShelf programs - has long been very important to the Polish tabletop RPG fandom. One could say that creating content by the community is a universal and unavoidable feature of RPG players. Dominik Porczyński (2014) argues that participating in tabletop roleplaying games is by definition prosumption: an activity where borders between production and consumption are hard to define (Siuda, Żaglewski, 2014). Porczyński catalogues a wide spectrum of prosumptive activities of RPG enthusiasts - from participating in a game session to writing one's own materials. He also notes that many professionally published RPGs started out as fan projects and variant rules for wargames (Porczyński, 2014). Tabletop roleplaying games originated as prosumptive and remain highly prosumptive to this day, not only in Poland.

However, RPG prosumption proliferates in periods and places where the official market of RPG goods is relatively small. Porczyński (2014) shows how a huge number of official games and supplements limits RPG-related prosumption by giving fans less space for creating their own 
materials. Moreover, Shannon Appelcline's (2014a) history of the beginnings of the roleplaying industry documents a boom in the creation of fan content and house rules in the first years after the publication of Dungeons $\mathcal{E}$ Dragons in 1974 - when there were roleplayers already but there were not enough materials for roleplaying games to fulfill their needs so they had to produce such materials themselves ${ }^{1}$.

While the complete history of the Polish RPG market is beyond the scope of this paper, it is clear that in its beginnings it relied heavily on prosumption. The first roleplaying game was published in Poland in 1990, six years after the idea of roleplaying games had been first introduced in Poland in a press article (Kominiarczuk, 2013). This means that in the first years when any Polish audience was aware of the existence of roleplaying games, this medium saw no such bloom in professional publishing as in the first years of the hobby in the USA (Appelcline, 2014a) and the emerging group of fans was left to create more roleplaying content on their own. There were, of course, people playing imported games but there was no RPG professionally published in Poland. A very telling fact is that the first issue of Magia i Miecz (Sword and Sorcery), the longest-lasting Polish RPG magazine (1993-2002, 2014-ongoing) started its first issues by presenting, in five parts, a Polish RPG system: Kryształy Czasu (Crystals of Time) by Artur Szyndler, described by Mochocka and Mochocki as "a home-brew clone of DED" (2016, p. 185). This was not the very first Polish RPG, however, as three years earlier the Feniks magazine had published Andrzej Sapkowski's Oko Yrrhedesa (Eye of Yrrhedes), another fantasy game, this time strongly influenced by Jackson and Livingstone's Fighting Fantasy books (Sapkowski, 1995). The first mentions of DED itself appeared in the eighth issue of Magia i Miecz (3/1994) with an introduction to Advanced Dungeons \& Dragons and a scenario for this system (Mochocka, Mochocki, 2016).

1 This fact connects in an interesting manner to a way of researching tabletop RPGs suggested by Stanisław Krawczyk in his two papers published in Homo Ludens (Krawczyk, 2009 , 2010). Krawczyk's approach was to analyse RPGs as parts of popular culture, understood according to Marek Krajewski - as culture that provides controlled and diverse pleasure. In this approach diversity would be one of the factors deciding if roleplaying games are a satisfactory form of popular culture for their fans, and thus prosumption of new materials for those games could be viewed as an attempt to increase their diversity and, in turn, the pleasure they deliver. 
While fan creativity from this period is notoriously hard to track and research, Oko Yrrhedesa and Kryształy Czasu are already examples of prosumption. The first RPGs available in Poland were not established games from abroad. Instead, they were Polish systems, and their publication can be viewed as a prosumptive answer to English-language RPGs.

If prosumption is generally deeply connected to tabletop RPGs, this connection runs even deeper in times and areas where the professional market is not strongly developed - both because fans usually try to "fill in the holes" with their own creations and because the smaller the professional market, the more blurred the boundary between a fan and a professional publisher or designer. It seems that in Poland, due to the realities of the market, the sort of prosumptive fan activity that could find a creative outlet in community content programs was initially welcome - or even necessary - for a long enough time to become an important aspect of Polish RPG fandom. While the first years of the 21st century saw a growth in professional RPG market in Poland, they also saw a proliferation of fan websites dedicated to the hobby, usually posting vast amounts of fan material for various games as well as homebrew systems (Kominiarczuk, 2013). Then, once again - why are there almost no Polish designers in OneBookShelf programs?

Or, to be more precise - why are there almost no Polish RPG designers who started their careers in such programs? Since the first version of this article was written in December 2018, there has been a huge growth in the amount of Polish materials available in community content programs. The authors of those materials, however, are mostly people with previous experience in professional RPG publishing.

First, Polish supplements for the fifth edition of Dungeons \& Dragons began appearing on Dungeon Masters Guild. The most popular among them are, however, by none other than Jan Sielicki ${ }^{2}$. Apart from Sielicki's adventures and translations, Dungeon Masters Guild offers materials by Andrzej Stój, a professional RPG designer with a long history of both Polish and English publications; by another experienced RPG designer

2 His Polish offer includes Kłopoty z Goblinami (Goblin Trouble), an introductory scenario for beginning players and Dungeon Masters, as well as translations of popular English texts by other authors (Dungeon Masters Guild, 2019). 
Jakub Osiejewski; and by Miłosz Gawęcki (Dungeon Masters Guild, 2019). More supplements will probably be published soon by various authors, leaving any list I could make in this analysis temporary and incomplete. It seems that wider production of community content material by people without previous experience in RPG design (shared by Sielicki, Stój, and Osiejewski) is still nothing more than a future possibility.

Second, I myself have published materials under the community content license for Call of Cthulhu $7^{\text {th }}$ Edition within the Miskatonic Repository. With a few cooperators I have started releasing a series of scenarios and other supplements titled Zgrozy ${ }^{3}$ (The Horrors). While Zgrozy has become unexpectedly popular in Poland (see, for example, its ratings and reviews in Miskatonic Repository, 2019), the very fact that I - an RPG designer with over five years of experience in both Polish and English markets am its main coordinator, proves again that creating community content in Polish is so far done mostly by people with previous experience in RPG design.

\section{Possible answers}

One part of the answer is the fact that probably has not been researched yet but has been mentioned in many conversations during conventions and other fandom meetings I took part in. Namely: Polish RPG culture is not used to the digital market. Most Polish publishers have included PDFs in their offer relatively lately, if at all. Their reluctance to publish PDFs might have come partially from the fear of piracy ${ }^{4}$ but during my personal communication with Polish RPG publishers since 2012 I have also often heard that digital books are simply unattractive to the Polish RPG fandom and most people active in the hobby much prefer to have

3 As of the beginning of September 2019, the series consists of eight supplements five by me, two by Michał Gralak, one by Jacek Radzymiński (Miskatonic Repository, 2019).

4 I have heard numerous complaints from Polish RPG fans that Wolsung core rulebook, not released as a PDF and unwieldy to be scanned (paperback, 500 pages), cannot be found on Polish illegal file-sharing sites. Sharing that remark openly, even though the people complaining were sometimes aware that I had been writing supplements for the Wolsung product line, was a striking example of how the practice of illegal file downloads is not only widespread but also accepted and considered natural. 
printed books ${ }^{5}$. If those opinions are correct, they partially explain why there is almost no community content in Polish. But this is probably not the only explanation - and it does not account for the fact that one Polish person, Jan Sielicki, is regularly publishing English content in those programs.

A part of the answer might also be concealed in the origins of the hobby in Poland and thus a relatively long absence of Dungeons $\mathcal{E}$ Dragons here. Because it did not get a successful release in the nineties (Kominiarczuk, 2013; Muszyński, 2016), its position in the Polish fandom is not as hegemonic as in the American one. This can be best seen when we notice that DED and Warhammer Fantasy Roleplay ${ }^{6}$ are often treated as equals by Polish fans - two main fantasy games, one heroic, the other one dark (Porczyński, 2014) ${ }^{7}$. Dungeon Masters Guild is not the only affiliate program but it is the oldest and biggest one. Furthermore, the approach of DED's publisher to licensing had caused a growth of a community of both amateur and professional creators before Dungeon Masters Guild opened thanks to its open licenses (Appelcline, 2014b). In Poland there were next to none supplements written and published under those earlier licenses. Dungeons \& Dragons has had the role of a trendsetter in the open licenses market (Appelcline 2014c) and it is possible that without this trendsetter the awareness of such licenses and a willingness to use them is lower in Poland. This might in turn result in a lowered interest in the open system licenses' newest form - community content programs.

The language barrier is a related problem. Dungeon Masters Guild accepts supplements only for the fifth edition of DED, so before the Polish translation of this edition was published, the potential reach

5 RPG publishers sometimes also explain this reluctance to release PDFs by the fact that the difference between the cost of a printed book and a PDF is generally lower in Polish stores than in the English-language market, including OneBookShelf stores. Due to their relatively high prices, PDFs are apparently seen as unattractive, so the publishers do not have an incentive to invest in offering them for sale.

6 A game released by MAG in 1994 and further embedded in the Polish roleplaying fandom by the famous Jesienna Gawęda (The Autumn Tale) gamemastering advice series by Ignacy Trzewiczek (Mochocka, Mochocki, 2016).

7 It might be a coincidence but in late December 2018 the only two Polish community content supplements were both intended for use with Zweihänder, a game strongly inspired by Warhammer Fantasy Roleplay. 
of Polish-language materials for this game had been limited. Other community content programs - in particular Storyteller's Vault - have allowed fans to publish materials for older editions of their respective games, many of them available in Polish, but since Dungeon Masters Guild is the first and biggest of community content programs, the lack of chances to publish Polish-language materials there might have greatly decreased Polish interest in community content programs as a whole. The language barrier problem might also connect to the aforementioned flourish of Polish RPGrelated websites and blogs in the early $21^{\text {st }}$ century. There were many places for Polish-language publication of RPG materials with a relatively high chance of being noticed and commented or even reviewed, offering a natural venue for Polish amateur creators and thus limiting their interest in venues for English-language publication. This might have led to Polish RPG creators having little interest in English-language publication, including most of community content programs. And, of course, most of them are less competent in English than Sielicki, a professional English teacher. The idea of publishing in English might thus have been intimidating to them.

The final part of the answer requires me to quote my interview with the aforementioned Jan Sielecki. When asked about what his assets were when he began publishing in community content programs, Sielecki answered (personal communication, $18^{\text {th }}$ December 2018):

I guess I'm self-taught. There are no online courses for this, at least there weren't two years ago. I wasn't a member of any RPG community either. What I had was over 20 years of experience in RPGs. [...] However, I used to be a teacher of English as a foreign language and that profession requires certain skills, such as planning, getting your ideas across, the ability to see the different expectations of your students, or a structural approach to lesson planning and execution, all that, quite unexpectedly, became useful when I sat down to work on "The Bridges we Burn”...

This answer from Sielicki was quite unexpected, particularly in conjunction with the next one - the answer to a more detailed question about his experiences with the Polish RPG fandom:

J.S.: I've never played any Polish system for long. [...] However, Magia i Miecz and later Złoty Smok were important. [...] At the time access to the Internet was difficult and those Magia i Miecz issues were practically the only source of information on RPGs and how to play. That said, I've never treated them as Holy Bible, they were just useful. I quickly switched to RPGs in English. 
M.G.: Do you see any connection between how you write your RPG materials now and what you learned from Magia i Miecz and Złoty Smok?

J.S.: No, I don't think there is a direct connection. Magia i Miecz and Złoty Smok were so long ago, I don't really remember what was in there, and decades passed before I actually started writing and publishing.

Two most striking pieces of information in those answers are that Sielicki does not feel strongly influenced by any element of the Polish RPG fandom - and given how early he became disconnected from it, he might well be right - and that he stresses his organizational and communicative skills gained as an English teacher as the most important factors of his success besides his roleplaying experience. While those answers show only Sielicki's self-perceptions, after numerous conversations with would-be game designers and observing their online discussions I believe his views to be quite accurate and to hint at another, maybe the most important aspect of Polish absence in community content programs.

While the prosumptive approach and creation of fan-made content described in earlier sections surely are important aspects of the Polish RPG fandom, they do not necessarily go hand in hand with the skills necessary to design a communicative RPG product. The analysis of the initial issues of Magia i Miecz by Mochocka and Mochocki (2016) suggests that guides and advice published there were, quite logically, centered around gamemastering and preparing sessions for players. This summary does not mention any advice on preparing scenarios or other game elements as supplements for other people. Judges of the first editions of Quentin, the oldest Polish RPG scenario contest (1999-ongoing), mentioned (personal communication, $28^{\text {th }}$ to $30^{\text {th }}$ December 2018) organizing various scenario design workshops during Polish conventions in the early years of the competition (mostly 2000-2005), but those workshops were not recorded or written down, so they probably reached a relatively small number of people - and a part of this small number probably were not active in RPG fandom anymore when the community content programs were launched.

It is also worth noting that the website of Quentin contains a few short articles written by the judges about common Quentin errors and most of them refer to problems of form, not content (Bogdaszewski, 2018; Doraczyński, 2018; Sołtysiak, 2018). These articles seem to suggest that 
Quentin judges have noticed more problems with writing an idea down than with coming up with it - RPG fandom members who participate in this contest seem to be much more creative than skilled in writing game supplements. In other words, they lack precisely those skills Sielicki considers his major advantage. As a Quentin judge in three editions of the contest I can also support this hypothesis with my own experience - when evaluating the scenarios I have noticed that their main disadvantage usually is not a lack of good ideas but a lack of the ability to, to borrow Sielicki's phrase, "get their ideas across". While Quentin scenarios are not representative of Polish RPG fandom prosumption as a whole, Krawczyk (2009) has suggested that they will probably be more complex and better thought-through than average Polish fan-made scenarios. If this trend is visible even in Quentin texts, the problem will probably be even more visible in other Polish fan-made RPG materials.

\section{Prosumption and publishing}

The creativity of the members of the Polish RPG fandom and their ability to engage in various forms of prosumption has been proven over and over again in various creative outlets. However, it seems difficult to transform into participation in community content programs. An analysis of this difficulty can shed an interesting light on both the Polish RPG fandom and the community content programs.

The absence of Polish authors in community content programs could be seen as another indicator of Dungeons \& Dragons' trendsetting role in the RPG market - DED's publishers keep experimenting with various modes of activity in the RPG industry and community content programs are the next step after earlier open licenses. Since $D E D$ is not as domineering in Poland as in the USA and the earlier licenses have remained almost unused in our country, the publishing tradition to which community content programs refer just does not exist in Poland. This reason is close to another one - the Polish e-book market for RPGs is very weakly developed, causing a relative lack of interest in OneBookShelf web-shops and thus also in their sub-shops: community content programs. An even more fundamental reason might be the fact that in Poland there are very 
few possibilities to actually learn the craft of creating RPG supplements. Advice about preparing and running a session is relatively easy to find but this sort of experience does not translate directly into an ability to write down a material intended for use by other players or game masters. Jan Sielicki states that his success in community content programs is partly due to organization and communication skills gained independently of his RPG expertise. If he is right, this actually lowers the chances of the Polish RPG fandom members to become community content publishers since the skills Sielicki mentions are actually hard to learn within the Polish RPG fandom.

I believe this analysis suggests an important aspect of RPG prosumption as a whole. Small RPG markets with few publishers and a very blurred line between a fan and a professional (like the Polish one) can be stimulating for fan creativity but simultaneously they provide less know-how needed to actually prepare an RPG supplement as a commercial product. If this assumption is true, then the RPG community in such countries would on the one hand be less able to allow its members to cross the threshold into professional or semi-professional game design, but on the other hand it would possibly be more stimulating for amateur projects.

It seems impossible (and unnecessary) to judge if this trait of the Polish and other similar RPG markets is positive or negative. This paper tries to explain the Polish RPG fandom's "failure" to produce community content creators but failing at this task does not indicate any sort of failure of the Polish RPG community as a whole. A further study concerning the potential positive aspects of this situation for the Polish RPG community would be most interesting. It is, however, beyond the scope of this paper.

\section{References}

Appelcline S. (2014a). Designers \& Dragons. History of the roleplaying game industry: '70 to '79. USA: Evil Hat Productions.

Appelcline S. (2014b). Designers \& Dragons. History of the roleplaying game industry: '9o to '99. USA: Evil Hat Productions.

Appelcline S. (2014C). Designers \& Dragons. History of the roleplaying game industry: 'oo to 'o9. USA: Evil Hat Productions. 
Bogdaszewski, P. (2018). Quentinowe błędy [blog post]. Online: <http:// kwentin.vot.pl/?page_id=2007>.

Doraczyński, W. (2018). Style over substance! [blog post]. Online: <http:// kwentin.vot.pl/?page_id=1149>.

Kominiarczuk, M. M. (2013). Roleplaying games na przykładzie Dungeons $\mathcal{E}$ Dragons. Przyczynek do ujęcia historyczno-kulturowego. Wrocław: unpublished M.A. thesis.

Krawczyk, S. (2009). Ciągle ta sama historia? O powtarzalności fabuł w narracyjnych grach fabularnych. Homo Ludens, 1(1), 137-153. Online: $<$ http://ptbg.org.pl/HomoLudens/vol/1/>.

Krawczyk, S. (2010). Badacz z fanem w jednym domu. O potrzebie kontaktów $\mathrm{z}$ fandomem $\mathrm{w}$ badaniach nad narracyjnymi grami fabularnymi. Homo Ludens, 1(2), 61-75. Online: <http://ptbg.org.pl/HomoLudens/ $\mathrm{vol} / 1 />$.

Mochocka, A., Mochocki, M. (2016). Magia i Miecz Magazine: The Evolution of Tabletop RPG in Poland and its Anglo-Saxon Context. Homo Ludens, 8(1), 167-196. Online: <http://ptbg.org.pl/HomoLudens/vol/9/>. Montgomery J. (2017). How to become a publisher on our site [web FAQ article]. Online: <https://support.rpgnow.com/hc/en-us/articles/209936663How-to-become-a-publisher-on-our-site $>$.

Montgomery J. (2018a). Content and Format Questions [web FAQ article]. Online: <https://support.dmsguild.com/hc/en-us/articles/217029298Content-and-Format-Questions>.

Montgomery J. (2018b). Payment and Pricing Questions [web FAQ article]. Online: <https://support.dmsguild.com/hc/en-us/articles/217520767Payment-and-Pricing-Questions $>$.

Montgomery J. (2018c). What is Dungeon Masters Guild [web FAQ article]. Online: <https://support.dmsguild.com/hc/en-us/articles/217028508What-is-the-Dungeon-Masters-Guild $>$.

Muszyński P. (2016). Advanced Dungeons and Dragons - w to się kiedyś grało [blog post]. Online: <https://fanbojizycie.wordpress.com/2016/01/27/ advanced-dungeons-and-dragons-w-to-sie-kiedys-gralo/>.

OneBookShelf (2018a). About us [web FAQ article]. Online: <https://www. dmsguild.com/about.php>.

OneBookShelf (2018b). Community Content Programs [web FAQ article], $<$ https://www.drivethrurpg.com/cc/o/default>. 
OneBookShelf (2019a). Dungeon Masters Guild, Polish products category [shop subsite], Online: < https:// www.dmsguild.com/browse.php?fil ters=0_O_O_O_O_O_O_45485>.

OneBookShelf (2019b). Miskatonic Repository, Polish products category [shop subsite], <https://www.drivethrurpg.com/browse/pub/2/Chaosium/subcategory/29274/Miskatonic-Repository?filters=O_O_O_O_453 $38 \&$ sort $=4 a>$.

Pinnacle Entertainment Group (2018). Announcing the Savage Worlds Adventurer's Guild! [blog post], Online: <https://www.peginc.com/ announcing-the-savage-worlds-adventurers-guild/>.

Porczyński D. (2014). Prosumpcja w polskim fandomie gier fabularnych. In Siuda P., Żaglewski T. (Eds.), Prosumpcja: pomiędzy podejściem apokaliptycznym a emancypującym (pp. 99-138). Gdańsk: Wydawnictwo Naukowe Katedra.

Sapkowski, A. (1995). Oko Yrrhedesa. Warszawa: Wydawnictwo MAG.

Siuda P., Żaglewski T. (2014). O potrzebie odkrycia trzeciej drogi w badaniach prosumpcji. In Siuda P., Żaglewski T. (Eds.), Prosumpcja: pomiędzy podejściem apokaliptycznym a emancypującym (pp. 7-21). Gdańsk: Wydawnictwo Naukowe Katedra.

Sołtysiak, M. (2018). Jak pisać scenariusz na konkurs Quentin? [PDF]. Online: $<$ http://kwentin.vot.pl/?page_id=1117>.

All the Internet sources were consulted on the $2^{\text {nd }}$ July 2019 .

Marek Golonka, M.A. - Role-Playing Games designer, Ph.D. student at the Institute of Polish Culture at University of Warsaw and game design lecturer at Kazimierz Wielki University in Bydgoszcz and Górnośląska Wyższa Szkoła Przedsiębiorczości w Chorzowie.

\section{Programy community content platformy OneBookShelf a polski fandom RPG}

Abstrakt: Artykuł analizuje nieomal zupełny brak udziału polskich projektantów gier fabularnych w programach community content otworzonych przez OneBookShelf dla różnych systemów RPG i proponuje wyjaśnienie tego stanu warunkami rozwoju fandomu gier fabularnych w Polsce. Jako częściowa przyczyna zasugerowana jest pozycja Dungeons \& Dragons na 
polskim rynku RPG, słabsza niż na rynku anglojęzycznym, i niskie zainteresowanie polskich graczy rynkiem cyfrowych materiałów do narracyjnych gier fabularnych. Główne przypuszczenie łączyjednak brak polskiego udziału w programach community content $\mathrm{z}$ długą nieobecnością profesjonalnie wydawanych gier fabularnych na krajowym rynku RPG oraz jego trwającą do dzisiaj niewielką skalą. Czynniki te mogły zintensyfikować prosumpcję gier fabularnych wśród ich polskich fanów, ale zarazem ograniczyty ich szanse na zdobycie umiejętności i wiedzy potrzebnych, by publikować i sprzedawać efekty tej prosumpcji na (pót)profesjonalnym poziomie. 0pinie Jana Sielickiego - jedynego polskiego projektanta RPG publikującego liczne i dobrze przyjęte dodatki w ramach programów community content wzmacniają to przypuszczenie i pokazują, jak Sielicki zdobył potrzebne umiejętności poza polskim fandomem narracyjnych gier fabularnych.

Słowa kluczowe: community content, Dungeon Masters Guild, prosumpcja, gry fabularne, RPG 